J. Perinat. Med. 17 (1989) 453

\section{Beta-2-microglobulin in the assessment of renal function in full term newborns following perinatal asphyxia}

\author{
Fernando Fernandez ${ }^{2}$, Vicente Barrio', Juana Guzman², Maria Dolores Huertas², \\ Mercedes Zapatero' ${ }^{2}$, Maria Dolores de Miguel $^{2}$, and Jesus Mallol $^{3}$
}

${ }^{1}$ Service of Nephrology, ${ }^{2}$ Unit of Neonatology, Department of Pediatrics, and ${ }^{3}$ Service of Nuclear Medicine, "Reina Sofia" Hospital, Córdoba, Spain

\section{Introduction}

Perinatal asphyxia has been recognized as a cause of acute renal failure (ARF) in the newborn $[1,8,19]$. The initial response to intrauterine hypoxia is a redistribution of cardiac output with a decrease in renal perfusion among other organs, in order to preserve perfusion to vital organs including brain, heart, and adrenal glands $[4,6]$. Renal proximal tubule is particularly susceptible to hypoxia [20], as reflected by a marked decrease in reabsorption capacity following this insult. Beta-2 microglobulin $\left(\beta_{2}-\mathrm{m}\right)$ is a low molecular weight protein freely filtered through the glomerular capillary wall and almost completely reabsorbed by proximal tubular cells. Therefore, urinary excretion of $\beta_{2}-\mathrm{m}$ is very small $[18,21]$. Tubular damage secondary to hypoxia [7, 22], ischemia [13], and nephrotoxic agents $[2,11]$ results in increased urinary levels of $\beta_{2}-\mathrm{m}$.

The aim of the present study was to evaluate the clinical usefulness of $\beta_{2}-\mathrm{m}$ determination in serum and urine in the diagnosis of renal dysfunction in full term neonates following asphyxia, and to compare these tests with traditional indices of renal function such as plasma creatinine $(\mathrm{Cr})$, endogenous creatinine clearance (Ccr), and fractional sodium excretion.

\section{Methods}

From December 1986 through March 1988, forty full term newborns were studied. The group of asphyxiated infants comprised twenty newborns with a mean birth weight of $3180 \pm 325 \mathrm{~g}$, all

\section{Curriculum vitae}

Fernando Fernandez, M.D., was graduated from Cantabria University in 1979 and qualified as a specialist in Pediatrics at Children's Hospital "La Paz" Madrid, Spain in 1984. He had a fellowship in Neonatology at the same Hospital in 1984. Since 1986 he has been on the staff of

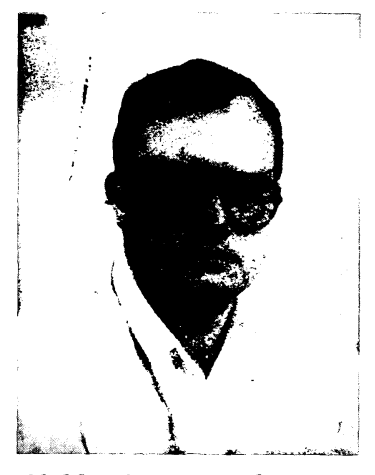
Department of Pediatrics, Children's Hospital "Reina Sofia", Córdoba, Spain. His main research interest is in the field of perinatal asphyxia.

of which met at least three of the following criteria:

\section{Abnormal fetal heart rate monitoring}

2. Apgar score under 4 at one minute, and under 6 at five minutes of life

3. Requirement for more than one minute of positive pressure ventilation before spontaneous sustained respiration occurred

4. Metabolic acidosis with $\mathrm{pH}<7.2$ within twenty minutes of birth.

The control group included twenty full term infants with a mean birth weight of $3271 \pm 295 \mathrm{~g}$ who were delivered normally after an uncomplicated pregnancy. None of them presented clinical nor biochemical signs of asphyxia. 
None of the infants showed major congenital abnormalities, respiratory distress syndrome, cardiac dysfunction, hyperbilirubinemia, renal disease nor received nephrotoxic drugs. All asphyxiated infants were given $60 \mathrm{ml} / \mathrm{kg}$ of iv fluid ( $10 \%$ dextrose in water) on the first day of life. Fluid and electrolyte intake was subsequently adjusted according to patient's clinical status. Infants in the control group received formula during the first four to six hours after birth and were thereafter fed ad libitum every three hours.

Renal function was evaluated in both groups on the first and third day of life by means of serum and urinary levels of creatinine, sodium, and $\beta_{2^{-}}$ $\mathrm{m}$. Timed 8 hours urine samples were collected using a urine bag placed over the infant's external genitalia. Manual suprapubic pressure was applied at the end of the collection interval to ensure completeness. When urinary $\mathrm{pH}$ was less than 6.0, alkalinazation was obtained with sodium hydroxide to prevent $\beta_{2}$-m inactivation. At the midpoint of urine collection, $3 \mathrm{ml}$ of blood were drawn from an umbilical catheter or peripheral vein and immediately centrifuged. Serum and urine samples were stored at $-20^{\circ} \mathrm{C}$ until analyzed. $\beta_{2}-\mathrm{m}$ was measured by radioimmunosorbent assay (Phadebas, $\beta 2$ microtest, Pharmacia Diagnostics, Uppsala, Sweden).

Creatinine clearance, fractional excretion of sodium $(\mathrm{FeNa})$, and fractional excretion of $\beta_{2}-\mathrm{m}$ $\left(\mathrm{Fe} \beta_{2}-\mathrm{m}\right)$ were calculated as follows:

$$
\begin{aligned}
& \mathrm{Ccr}\left(\mathrm{ml} / \mathrm{min} 1.73 \mathrm{~m}^{2}\right)=(\mathrm{V} \mathrm{Ucr} / \mathrm{Pcr})(1.73 / \\
& \mathrm{BSA}) \\
& \mathrm{CNa}\left(\mathrm{ml} / \mathrm{min} 1.73 \mathrm{~m}^{2}\right)=(\mathrm{V} \mathrm{UNa} / \mathrm{PNa}) \\
& (1.73 / \mathrm{BSA}) \\
& \mathrm{FeNa}(\%)=\mathrm{CNa} / \mathrm{Ccr} \\
& \mathrm{C} \beta_{2}-\mathrm{m}\left(\mathrm{ml} / \mathrm{min} 1.73 \mathrm{~m}^{2}\right)=\left(\mathrm{V} \mathrm{U} \beta_{2}-\mathrm{m} / \mathrm{P} \beta_{2}-\mathrm{m}\right) \\
& (1.73 / \mathrm{BSA}) \\
& \mathrm{Fe} \beta_{2}-\mathrm{m}(\%)=\mathrm{C} \beta_{2}-\mathrm{m} / \mathrm{Ccr}
\end{aligned}
$$

where BSA $=$ Body Surface Area, $\mathrm{C}=$ Clearance, $\mathrm{Na}=$ Sodium $(\mathrm{mEq} / \mathrm{l}), \mathrm{Cr}=$ creatinine $(\mathrm{mg} / \mathrm{dl}), \mathrm{V}=$ Urine flow ( $\mathrm{ml} / \mathrm{min}), \mathrm{P}=$ Plasma, $\mathrm{U}=$ Urine.

All results are given as the mean \pm one standard deviation. Statistical analysis was performed with Statistical Analysis System (SAS) software [17], and included Student's t test for unpaired data, and repeated measures analysis of variance. Multiple comparisons were adjusted according to Scheffe's multiple $F$ tests on all main-effect means. Correlation coefficients were determined; $P$ values $<0.05$ were considered significant. Sen- sitivity, and specificity of urinary $\beta_{2}-\mathrm{m} / \mathrm{Cr}$ ratio, $\mathrm{Fe} \beta_{2}-\mathrm{m}$, and $\mathrm{FeNa}$ as indices of proximal tubular injury following asphyxia were evaluated.

\section{Results}

In the group of asphyxiated infants, 11 out of 20 presented oliguria defined by a urinary flow rate of less than $0.8 \mathrm{ml} / \mathrm{kg}$ per hour and 5 oliguric acute renal failure defined by a urinary flow rate of less than $1.0 \mathrm{ml} / \mathrm{kg}$ per hour which failed to respond to volume repletion along with serum creatinine greater than $1.5 \mathrm{mg} / \mathrm{dl}$. Ten asphyxiated infants with oliguria presented Apgar scores under 4 at 5 minutes of life and $\mathrm{pH}$ $<7.10$.

A summary of global results on the first and third day of life for both groups of patients is displayed on table I. Significant differences between controls and asphyxiated full term infants were found, on both day 1 and 3, for serum creatinine $(p<0.01)$, endogenous creatinine clearance $(p<0.01)$, urinary $\beta_{2}-m /$ creatinine ratio $(\mathrm{p}<0.01)$, fractional $\mathrm{Na}$ excretion $(\mathrm{p}<0.01)$, and fractional excretion of $\beta_{2}-\mathrm{m}$ $(\mathrm{p}<0.01)$. On the other hand, no differences were observed in serum $\beta_{2}$-m.

In asphyxiated neonates stratified by the presence or absence of oliguria or acute renal failure as defined above (table II), infants with oliguria presented significantly higher values of serum creatinine $(\mathrm{p}<0.05)$ and $\mathrm{Fe} \beta_{2}-\mathrm{m}(\mathrm{p}<0.05)$ on the first day of life. Urinary $\beta_{2}-\mathrm{m} /$ creatinine ratio was only significantly increased in infants with oliguria. On day 3 , serum creatinine levels were only significantly elevated in asphyxiated infants with acute renal failure. No significant differences in creatinine clearance, FeNa, urinary $\beta_{2}$ $\mathrm{m} /$ creatinine, nor in $\mathrm{Fe} \beta_{2}-\mathrm{m}$ were observed.

In asphyxiated infants on the first day of life, urinary $\beta_{2}-\mathrm{m} /$ creatinine ratio was significantly correlated with serum $\beta_{2}-\mathrm{m}(\mathrm{r}=0.48, \mathrm{p}<0.05)$, FeNa $(r=0.59, p<0.01)$, and with $\mathrm{Fe} \beta_{2}-\mathrm{m}$ $(\mathrm{r}=0.70, \mathrm{p}<0.01)$, but not with serum creatinine. $\mathrm{Fe} \beta_{2}-\mathrm{m}$ was significantly correlated with $\mathrm{FeNa}(\mathrm{r}=0.66, \mathrm{p}<0.66, \mathrm{p}<0.01)$, but neither with serum $\beta_{2}-\mathrm{m}$, serum creatinine, nor with creatinine clearance. $\mathrm{FeNa}$ was not correlated with serum creatinine and neither with creatinine clearance. On day 3 , urinary $\beta_{2}-\mathrm{m} /$ creatinine ratio correlated with $\mathrm{FeNa}(\mathrm{r}=0.52, \mathrm{p}<0.05)$, and with $\mathrm{Fe}_{2}-\mathrm{m}(\mathrm{r}=0.53, \mathrm{p}<0.05)$. Addition- 
Table I. Summary of traditional renal function tests and determinations of $\beta_{2}-\mathrm{m}$ in serum and urine

\begin{tabular}{|c|c|c|c|c|c|c|}
\hline & $\begin{array}{l}\text { Serum Cr } \\
(\mathrm{mg} / \mathrm{dl})\end{array}$ & $\begin{array}{l}\text { Cr Clearance } \\
\left(\mathrm{ml} / \mathrm{min}^{2}\right. \\
\left.1.73 \mathrm{~m}^{2}\right)\end{array}$ & $\begin{array}{l}\mathrm{FeNa} \\
(\%)\end{array}$ & $\begin{array}{l}\text { Serum } \beta_{2}-\mathrm{m} \\
(\mu \mathrm{g} / \mathrm{ml})\end{array}$ & $\begin{array}{l}\text { Urinary } \\
\beta_{2}-\mathrm{m} / \mathrm{Cr} \\
(\mu \mathrm{g} / \mathrm{mg})\end{array}$ & $\begin{array}{l}\mathrm{Fe} \beta_{2}-\mathrm{m} \\
(\%)\end{array}$ \\
\hline \multicolumn{7}{|l|}{ Controls: } \\
\hline First day & $0.8 \pm 0.1$ & $31.7 \pm 5.2$ & $0.4 \pm 0.2$ & $3.4 \pm 0.5$ & $22.4 \pm 11.7$ & $4.9 \pm 3.0$ \\
\hline Third day & $0.6 \pm 0.1$ & $35.2 \pm 7.9$ & $0.3 \pm 0.1$ & $3.4 \pm 0.5$ & $21.1 \pm 9.6$ & $3.8 \pm 1.9$ \\
\hline \multicolumn{7}{|l|}{ Asphyctic: } \\
\hline First day & $1.1 \pm 0.2^{*}$ & $21.3 \pm 4.9^{*}$ & $1.2 \pm 0.5^{*}$ & $4.1 \pm 1.6$ & $62.2 \pm 31.6^{*}$ & $16.5 \pm 11.5^{*}$ \\
\hline Third day & $0.9 \pm 0.3^{*}$ & $27.4 \pm 7.8^{*}$ & $1.0 \pm 0.5^{*}$ & $3.7 \pm 1.4$ & $52.5 \pm 18.0^{*}$ & $13.8 \pm 9.4^{*}$ \\
\hline
\end{tabular}

Between groups comparisons on the same day $* \mathrm{p}<0.01$.

Table II. Summary of tests stratified by the presence of oliguria and of acute renal failure

\begin{tabular}{|c|c|c|c|c|c|}
\hline & $\begin{array}{l}\text { Serum Cr } \\
(\mathrm{mg} / \mathrm{dl})\end{array}$ & $\begin{array}{l}\text { Cr Clearance } \\
\left(\mathrm{ml} / \mathrm{min}^{2}\right. \\
\left.1.73 \mathrm{~m}^{2}\right)\end{array}$ & $\begin{array}{l}\mathrm{FeNa} \\
(\%)\end{array}$ & $\begin{array}{l}\text { Urinary } \\
\beta_{2}-\mathrm{m} / \mathrm{Cr} \\
(\mu \mathrm{g} / \mathrm{mg})\end{array}$ & $\begin{array}{l}\mathrm{Fe} \beta_{2}-\mathrm{m} \\
(\%)\end{array}$ \\
\hline \multicolumn{6}{|c|}{ Oliguria: (11) } \\
\hline $\begin{array}{l}\text { First day } \\
\text { Third day }\end{array}$ & $\begin{array}{l}1.3 \pm 0.3 \\
0.9 \pm 0.4\end{array}$ & $\begin{array}{l}20.2 \pm 5.6 \\
24.0 \pm 7.7\end{array}$ & $\begin{array}{l}1.5 \pm 0.7 \\
1.0 \pm 0.6\end{array}$ & $\begin{array}{l}78.3 \pm 42.2 \\
57.0 \pm 30.4\end{array}$ & $\begin{array}{l}22.7 \pm 13.5 \\
16.0 \pm 11.3\end{array}$ \\
\hline \multicolumn{6}{|c|}{ Normal diuresis: } \\
\hline $\begin{array}{l}\text { First day } \\
\text { Third day }\end{array}$ & $\begin{array}{l}1.0 \pm 0.1^{*} \\
0.9 \pm 0.3\end{array}$ & $\begin{array}{l}22.1 \pm 4.0 \\
24.8 \pm 7.7\end{array}$ & $\begin{array}{l}1.1 \pm 0.4 \\
0.9 \pm 0.4\end{array}$ & $\begin{array}{l}49.0 \pm 26.3^{*} \\
48.8 \pm 26.9\end{array}$ & $\begin{array}{l}11.6 \pm 5.7^{*} \\
12.5 \pm 7.1\end{array}$ \\
\hline \multicolumn{6}{|l|}{ ARF: (5) } \\
\hline $\begin{array}{l}\text { First day } \\
\text { Third day }\end{array}$ & $\begin{array}{l}1.5 \pm 0.1 \\
1.6 \pm 0.4\end{array}$ & $\begin{array}{l}16.8 \pm 2.7 \\
22.0 \pm 6.2\end{array}$ & $\begin{array}{l}1.6 \pm 0.6 \\
1.0 \pm 0.4\end{array}$ & $\begin{array}{l}65.2 \pm 35.0 \\
50.6 \pm 20.8\end{array}$ & $\begin{array}{l}26.4 \pm 11.4 \\
14.6 \pm 4.3\end{array}$ \\
\hline \multicolumn{6}{|c|}{ Normal function: } \\
\hline $\begin{array}{l}\text { First day } \\
\text { Third day }\end{array}$ & $\begin{array}{l}1.0 \pm 0.9^{*} \\
0.9 \pm 0.3^{*}\end{array}$ & $\begin{array}{l}22.8 \pm 4.3^{*} \\
25.2 \pm 7.9\end{array}$ & $\begin{array}{l}1.2 \pm 0.6 \\
1.0 \pm 0.5\end{array}$ & $\begin{array}{l}61.2 \pm 44.7 \\
53.1 \pm 30.7\end{array}$ & $\begin{array}{l}13.3 \pm 7.5^{*} \\
13.6 \pm 10.5\end{array}$ \\
\hline
\end{tabular}

Numbers in parentheses represent $\mathrm{n}$. Within groups comparisons on the same day ${ }^{*} \mathrm{p}<0.05$.

ally, $\mathrm{Fe} \beta_{2}-\mathrm{m}$ was significantly correlated with $\mathrm{FeNa}(\mathrm{r}=0.78, \mathrm{p}<0.01)$.

Values situated two standard deviations above the mean of the control group were considered as the upper limit of normal. According to this, on the first day of life 14 out of 20 asphyxiated neonates in contrast to only 1 neonate in the control group had elevated urinary $\beta_{2}$-m/creatinine ratio. Similarly, 15 out of 20 asphyxiated neonates and 1 in the control group had elevated levels of $\mathrm{Fe} \beta_{2}-\mathrm{m}$. Finally, 13 out of 20 asphyxiated neonates and 3 out of 20 in the control group presented elevated levels of FeNa. Sensitivity of urinary $\beta_{2}-\mathrm{m} /$ creatinine ratio, $\mathrm{Fe} \beta_{2}-\mathrm{m}$, and $\mathrm{FeNa}$ were $0.70,0.75$, and 0.65 , and specificity $0.95,0.95$, and 0.85 respectively.

\section{Discussion}

Results of the present study demonstrate that perinatal hypoxia causes impairment of tubular function as evidenced by an increase in urinary $\beta_{2}-\mathrm{m} /$ creatinine ratio, fractional excretion of $\beta_{2}$ $\mathrm{m}$, and fractional excretion of $\mathrm{Na}$. The degree 
of tubular dysfunction seems to be related to the severity of the ischemic insult since those neonates with more severe asphyxia, reflected by lower blood $\mathrm{pH}$ and Apgar scores, developed oliguria and/or acute renal failure, and had the highest levels of urinary $\beta_{2}-\mathrm{m} /$ creatinine ratio and $\mathrm{Fe} \beta_{2}-\mathrm{m}$ on the first day of life.

Values of serum $\beta_{2}-\mathrm{m}$ of the present study in the control group are consistent with previous reports $[10,3,23]$. There were no differences in serum $\beta_{2}$-m levels between the control group and those of asphyxiated infants. Additionally, serum $\beta_{2}-\mathrm{m}$ was neither correlated with serum creatinine nor with creatinine clearance. This precludes the use of serum $\beta_{2}-\mathrm{m}$ as an index of glomerular filtration rate in neonates, in contrast to adults where several studies have pointed out to its usefulness $[5,14]$.

Since it has been suggested that urinary $\beta_{2}-\mathrm{m}$ may be dependent on urine flow rate [10], although the point is controversial, urinary $\beta_{2}-\mathrm{m}$ was factored by urinary creatinine. Values of urinary $\beta_{2}-\mathrm{m} /$ creatinine ratio and $\mathrm{Fe} \beta_{2}-\mathrm{m}$ in the control group are similar to those reported in the literature $[10,3]$. Urinary $\beta_{2}-\mathrm{m} /$ creatinine ratio and $\mathrm{Fe} \beta_{2}-\mathrm{m}$ in the present study have shown significant increases both on the first and third day after asphyxia with respect to the control group.

When comparison was restricted to the neonates stratified by the presence or absence of oliguria or acute renal failure, only urinary $\beta_{2}-\mathrm{m} /$ creatinine ratio and $\mathrm{Fe} \beta_{2}$-m during the first day were significantly increased. Two previous reports indicate increased levels of urinary $\beta_{2}$-m secondary to proximal tubular dysfunction following perinatal hypoxia. Cole et al. [7], in a study including 65 full term newborns, found that infants with meconium stained amniotic fluid, mainly those with low Apgar score, presented elevated urinary $\boldsymbol{\beta}_{2}-\mathrm{m}$ levels. Recently, TACK et al. [22] described elevated urinary $\beta_{2}-\mathrm{m}$ levels in preterm and term asphyctic newborns. Urinary $\beta_{2}-\mathrm{m} /$ creatinine ratios in the present study display lower values, probably due to the inclusion in their study of preterm newborns, many of them less than 35 weeks which is the time when glomerular tubular balance is established [3]. Since serum $\beta_{2}-\mathrm{m}$ and urinary $\beta_{2}-\mathrm{m} /$ creatinine ratio were not correlated and did not differ significantly between control and asphyctic groups, we may suggest that serum $\beta_{2}-\mathrm{m}$ levels did not contribute to urinary $\beta_{2}-\mathrm{m}$ levels. Likewise, since no tubular maximum (Tm) for human $\beta_{2}-\mathrm{m}$ reabsorption has been found [12], the filtered load of $\beta_{2}-\mathrm{m}$ has little, if any, effect on urinary $\beta_{2}-\mathrm{m}$ levels.

$\mathrm{FeNa}$ has commonly been used to estimate renal tubular function in neonates [15, 16, 9]. Usually, a FeNa greater than 2.5 to $3 \%$ is present in most neonates with oliguric acute renal failure [16]. ELLIS and ARNOLD [9] found that a $\mathrm{FeNa}$ above $2.5 \%$ was present in all neonates with oliguric acute renal failure, but unfortunately similar figures were found in infants with prerenal oliguria. In the present study, although we observed elevated $\mathrm{FeNa}$ values in the group of asphyxiated neonates, $\mathrm{FeNa}$ was not able to discriminate between the presence or absence of oliguria or acute renal failure. On the first day of life, only 1 out of 5 of those infants who developed acute renal failure presented $\mathrm{FeNa}$ levels above $2.5 \%$. Therefore, FeNa seems to be less sensitive and specific than urinary $\beta_{2}-\mathrm{m} /$ creatinine ratio or $\mathrm{Fe} \beta_{2}-\mathrm{m}$ to identify tubular proximal dysfunction following perinatal asphyxia.

In summary, in the present study, urinary $\beta_{2}-\mathrm{m} /$ creatinine ratio and fractional excretion of $\beta_{2}-\mathrm{m}$ appear to be sensitive and specific tests for the early detection of renal proximal tubular dysfunction following perinatal asphyxia, providing better information than that obtained through traditional tests of renal function.

\begin{abstract}
In order to evaluate the clinical usefulness of serum and urinary $\beta_{2}$ microglobulin $\left(\beta_{2}-\mathrm{m}\right)$ determination as a marker of renal damage following perinatal asphyxia, twenty asphyxiated and twenty healthy full term newborns were studied. Renal function was monitored on the first and third day after birth by traditional tests such as creatinine $(\mathrm{Cr})$, endogenous creatinine clearance (Ccr), and fractional $\mathrm{Na}$ excretion ( $\mathrm{FeNa}$ ), as
\end{abstract}

well as by serum and urinary $\beta_{2}$ microglobulin. The value of different tests for the diagnosis of oliguria and of acute renal failure was determined. Eleven asphyxiated neonates developed oliguria and five ARF in contrast to none of the controls. Both traditional tests of renal function, and determinations of $\beta_{2}-\mathrm{m}$ with the exception of serum $\beta_{2}-\mathrm{m}$, were significantly different $(p<0.01)$ between controls and asphyxiated 
neonates. When stratified analysis was performed, only serum cr, urinary $\beta_{2}-\mathrm{m} / \mathrm{cr}$ ratio, and Fe $\beta_{2}-\mathrm{m}$ were able to discriminate oliguria from preserved diuresis on the first day of life. For ARF, only $\mathrm{Ccr}$ and $\mathrm{Fe} \beta_{2}-\mathrm{m}$ were different, again on the first day of life. Urinary $\beta_{2}-\mathrm{m} /$ creatinine ratio and $\mathrm{Fe} \beta_{2}$-m appear to be more sensitive and specific for the early detection of proximal tubular renal dysfunction following perinatal asphyxia than usual tests of renal function.

Keywords: $\quad \beta_{2}$ microglobulin, perinatal asphyxia, renal function tests, sensitivity, specificity.

\section{Zusammenfassung}

$\boldsymbol{\beta}_{2}$-Mikroglobulin als Parameter der Nierenfunktion bei Reifgeborenen nach perinataler Asphyxie

Um die Brauchbarkeit einer $\beta_{2}$-Mikroglobulin-Bestimmung $\left(\beta_{2}-\mathrm{m}\right)$ im Serum und Urin als Marker einer renalen Schädigung nach perinataler Asphyxie zu überprüfen, untersuchten wir 20 reife, asphyktische Neugeborene, auf die mindestens 3 der folgenden Kriterien zutrafen: 1. Pathologisches CTG. 2. Apgar-Score unter 4 eine Minute p.p. und unter 6 fünf Minuten p.p. 3. Notwendigkeit einer Beatmung mit positiven Drucken über mehr als eine Minute. 4. Metabolische Azidose mit einem $\mathrm{pH}<7,2$ in den ersten 20 Minuten. Zwanzig gesunde Neugeborene dienten als Kontrollgruppe. Am ersten und dritten Lebenstag wurde die Nierenfunktion durch konventionelle Methoden wie Creatininbestimmung $(\mathrm{Cr})$, endogene Creatinin-Clearance $(\mathrm{Ccr})$ und fraktionierte Natrium-Ausscheidung ( $\mathrm{FeNa}$ ) sowie auch durch radioimmunologische Messung des $\beta_{2}-\mathrm{Mi}$ kroglobulins im Urin $\left(\mathrm{Fe}_{2}-\mathrm{m}\right)$ und Serum bestimmt. Bei der Analyse der Daten erfolgte auch eine Zuordnung zu einer aufgetretenen Oligurie (Harnfluß geringer als $0,8 \mathrm{ml} / \mathrm{kg} / \mathrm{h}$ ) bzw. zu einem akuten Nierenversagen (Harnfluß geringer als $1,0 \mathrm{ml} / \mathrm{kg} / \mathrm{h}$, bei Volumenauffüllung keine Reaktion, Creatinin im Serum höher als $1,5 \mathrm{mg} / \mathrm{dl}$ ).

Elf asphyktische Neugeborene entwickelten eine Oligurie und fünf ein akutes Nierenversagen. Beide Komplikationen traten in der Kontrollgruppe nicht auf. Sowohl die konventionellen Tests wie auch das $\beta_{2}$-m im Urin, nicht aber das $\boldsymbol{\beta}_{2}$-m im Serum lieferten signi- fikant unterschiedliche Werte $(\mathrm{p}<0,01)$ zwischen Asphyxie- und Kontrollgruppe (Tab. I). Bei Klassifizierung (Tab. II) zeigte sich, daß hinsichtlich der Oligurie nur das Serumcreatinin, die $\beta_{2}-\mathrm{m} / \mathrm{Cr}$-Ratio und das $\mathrm{Fe} \beta_{-}-\mathrm{m}$ in der Lage waren, am ersten Lebenstag zwischen einer Oligurie und einer verzögerten Diurese zu unterscheiden. Bezogen auf ein akutes Nierenversagen waren am ersten Lebenstag lediglich $\mathrm{Ccr}$ und $\mathrm{Fe}_{2}$-m unterschiedlich. Am dritten Lebenstag fanden sich in allen Gruppen mit Ausnahme des Creatinin, nach dessen Höhe ein akutes Nierenversagen definiert wurde, keine Unterschiede. Die Sensitivität der $\boldsymbol{\beta}_{2}$-m/Cr-Ratio im Urin, des $\mathrm{Fe} \beta_{2}-\mathrm{m}$ und der $\mathrm{FeNa}$ betrug 0,70, 0,75 und 0,65 , die Spezifität lag bald bei $0,95,0,95$ und 0,85 .

Im Gegensatz zu Erwachsenen kann bei Neugeborenen das Serum- $\beta_{2}-m$ nicht als Parameter der glomerulären Filtrationsrate angesehen werden. Der Schaden im proximalen Tubulus nach Asphyxiw führt zu einer verminderten Reabsorption von $\boldsymbol{\beta}_{2}$-m und daraus folgend $\mathrm{zu}$ einer erhöhten $\beta_{2}$-m/Cr-Ratio im Urin wie auch eines vermehrten $\mathrm{Fe}_{2}$-m bei Oligurie. Nach der $\mathrm{FeNa}$ ist weder eine Zuordnung zu der Gruppe mit Oligurie noch zur Gruppe mit eingeschränkter Nierenfunktion möglich. Wir glauben daher, daß die $\beta_{2}-\mathrm{m} /$ Cr-Ratio im Urin und die $\mathrm{Fe}_{2}-\mathrm{m}$ sensitive und spezifische Tests zur frühen Erkennung einer Störung des proximalen Tubulus nach perinataler Asphyxie darstellen.

Schlüsselwörter: $\quad \boldsymbol{\beta}_{2}$-Mikroglobulin, Nierenfunktiontests, perinatale Asphyxie, Sensitivität, Spezifizität.

\section{Résumé}

La $\beta_{2}$ microglobuline dans l'appreciation de la fonction renale des nouveaux-nes a terme apres asphyxie perinatale

On a étudié vingt nouveaux-nés à terme ayant subi une asphyxie avec au moins trois des critères suivants: 1. surveillance du rythme cardiaque anormale, 2 . score d'Apgar inférieur à 4 à une minute, et inférieur à 6 à 5 minutes de vie, 3 . nécessité d'une ventilation à pression positive supérieure à une minute, 4 . acidose métabolique avec $\mathrm{pH}<7,2$ au cours des 20 minutes après la naissance, ainsi que vingt nouveaux-nés à terme bien portants afin d'évaluer l'utilité clinique du dosage sé- rique et urinaire de la $\beta_{2}$ microglobuline $\left(\beta_{2}-\mathrm{m}\right)$ comme marqueur de lésions rénales secondaires à une asphyxie périnatale. On a surveillé la fonction rénale au premier et au troisième jour après la naissance au moyen des tests traditionnels tels que la créatinine $(\mathrm{Cr})$, la clearance de la créatinine endogène $(\mathrm{Ccr})$ et l'excrétion fractionnelle du sodium ( $\mathrm{FeNa}$ ), ainsi que au moyen du dosage radio-immunologique sérique et urinaire de la $\beta_{2}$ microglobuline. On a analysé les données pour le groupe dans son ensemble et après réalisation de sous groupes en fonction de la présence d'une oligurie définie par un débit urinaire inférieur à $0,8 \mathrm{ml} / \mathrm{Kg} /$ heure 
et d'une insuffisance rénale aigüe (IRA) définie par un débit urinaire inférieur à $1,0 \mathrm{ml} / \mathrm{Kg} / \mathrm{heure}$, ne répondant pas à un remplissage avec une créatinine sérique supérieure à $1,5 \mathrm{mg} / \mathrm{dl}$.

Onze nouveaux-nés asphyxiés ont présenté une oligurie et cinq une IRA, contre aucun des témoins. Tous les tests traditionnels de la fonction rénale ainsi que les dosages de la $\beta_{2}-\mathrm{m}$, à l'exception de la $\beta_{2}-\mathrm{m}$ sérique, étaient significativement différents $(p<0,01)$ entre les nouveaux-nés témoins et asphyxiés (tableau I). Avec l'analyse des sous-groupes (tableau II) seuls la $\mathrm{Cr}$ sérique, le ratio $\beta_{2}$-m urinaire $/ \mathrm{Cr}$ et $\mathrm{Fe} \beta_{2} \mathrm{~m}$ permettent de discriminer l'oligurie de la diurèse conservée au cours du premier jour de vie. En ce qui concerne l'IRA, seuls la $\mathrm{Ccr}$ et la $\mathrm{Fe} \beta_{2}$-m étaient différents, également au cours du premier jour de vie. On n'a pas observé de différences au troisième jour quel que soit le groupe, à l'exception de la Cr qui est utilisée pour définir l'IRA.
Les sensibilités du ratio $\beta_{2}$-m urinaire/créatinine, de la $\mathrm{Fe} \beta_{2}$-m et de la $\mathrm{FeNa}$ sont de $0,70,0,75$ et de 0,65 et les spécificités respectivement de $0,95,0,95$ et de 0,85 . En contraste avec la situation des adultes, la $\boldsymbol{\beta}_{2}$-m sérique ne peut être utilisée chez les nouveaux-nés comme index du taux de filtration glomérulaire. Les lésions tubulaires proximales rénales secondaires à une asphyxie périnatale semblent rendre compte de la capacité réduite de réabsorption de la $\beta_{2}$-m et par là, de l'augmentation du ratio $\beta_{2}-\mathrm{m}$ urinaire/Cr et de la $\mathrm{Fe}$ $\beta_{2}$-m trouvée en présence d'une oligurie. Le FeNA n'est pas utile pour placer le nouveau-né ni dans le groupe oligurique ni dans le groupe avec fonction rénale réduite. Ainsi, le ratio $\beta_{2}-\mathrm{m}$ urinaire/créatinine et la $\mathrm{Fe} \beta_{2}$ $\mathrm{m}$ apparaissent être des tests sensibles et spécifiques pour le dépistage précoce de la dysfonction tubulaire proximale rénale secondaire à l'asphyxie périnatale.

Mots-clés: Asphyxie périnatale, $\beta_{2}$ microglobuline, sensibilité, spécificité, tests de la fonction rénale.

Acknowledgement: This study was supported by a grant from Heinz Koch Foundation, 1988.

\section{References}

[1] ANAND SK: Acute renal failure in the neonate. Ped Clin North Am 29 (1982) 791

[2] Assadi FK, E Chow-Tung: Renal handling of beta-2-microglobulin in neonates treated with gentamicin. Nephron 49 (1988) 114

[3] Assadi FK, EG John, P Justice, L Fornell: $\boldsymbol{\beta}_{2}$ microglobulin clearance in neonates: index of tubular maturation. Kidney Int 28 (1985) 153

[4] Berhman RE, MH Lees, EN Peterson, CW de LANNOY, AE SEEDS: Distribution of the circulation in the normal and asphyxiated fetal primate. Am J Obstet Gynecol 108 (1970) 956

[5] Cejka J, C Flossie, K KithiER: Serum $\beta_{2}$-microglobulin levels in normal children and sex-linked agammaglobulinemia patients. Clin Chim Acta 47 (1973) 59

[6] Cohn He, EJ Sacks, MA Heymann, AM RuDOLPH: Cardiovascular responses to hypoxemia and ischemia in fetal lambs. Am J Obstet Gynecol 120 (1974) 817

[7] Cole JW, RJ Portman, Y Lin, JM Perlman, AM ROBSON: Urinary $\beta_{2}$-microglobulin in full terms newborns: evidence for proximal tubular dysfunction in infants with meconium stained amniotic fluid. Pediatrics 76 (1985) 958

[8] Dauber IM, AN Krauss, PS Symchych, PAM AULD: Renal failure following perinatal anoxia. J Pediatr 88 (1976) 851

[9] Ellis EN, WC ARNOLD: Use of urinary indexes in renal failure in the newborn. Am J Dis Child 136 (1982) 615
[10] ENGLE WD, BS ARANT: Renal handling of beta2-microglobulin in the human neonate. Kidney Int 24 (1983) 358

[11] GouYon JB, Y AujARD, A ABisRor, N LAudiGNON, P D'ATHIS, E JACQZ, D BIOU, JF DEMELIER, H MATHIEU: Urinary excretion of N-Acetyl-Glucosaminidase and beta-2-microglobulin as early markers of gentamicin nephrotoxicity in neonates. Rev Pharmacol Ther 10 (1987) 145

[12] Hall PW, M Chung-Park, CV Vacca, M LonDON, AQ CROWLEY: The renal handling of beta 2-microglobulin in the dog. Kidney Int 22 (1982) 156

[13] Hall PW, ES Ricanati: Renal handling of $\beta_{2}$ microglobulin in renal disorders: with special reference to hepatorenal syndrome. Nephron 27 (1981) 62

[14] Leroy D, F Mauriat, M Dechaux, N Chopin, M BROYERS, C SACHS: La $\beta_{2}$ microblobuline: index de la filtration glomerulaire chez l'enfant. Arch Fr Pediatr 41 (1984) 43

[15] Mathew OP, AS Jonas, E James, H Bland, T GROSHONG: Neonatal renal failure: usefulness of diagnostic indices. Pediatrics 65 (1980) 57

[16] NoRman ME, FK AsSADI: A prospective study of acute renal failure in the newborn infant. Pediatrics 63 (1979) 475

[17] SAS User's Guide. 5th Ed. Cary, North Carolina: SAS institute, Inc. 1985

[18] SchardiJn GHC, LW Statius van Eps: $\beta_{2}$ microglobulin: its significance in the evaluation of renal function. Kidney Int 32 (1987) 635 
[19] Stapelton FB, DP Jones, RS Green: Acute renal failure in neonates: incidence, etiology, and outcome. Pediatr Nephrol 1 (1987) 314

[20] Stark H, R Geiger: Renal tubular dysfunction following vascular accidents of the kidneys in the newborn period. J Pediatr 83 (1973) 933

[21] Statius van EPS LW, GHC SchardiJn: $\beta_{2}$ microglobulin and the renal tubule. In: LuBEC $G$ (ed): Non-invasive diagnosis of kidney disease. Karger, Basel 1983, 103

[22] TACK ED, JM Perlman, AM Robson: Renal injury in sick newborn infants: a prospective evaluation using urinary $\boldsymbol{\beta}_{2}$-microglobulin concentrations. Pediatrics 81 (1988) 432
[23] Takieddine F, M Tabbara, P Hall, RJ Sokol, KC KING: Fetal renal maturation. Studies on urinary beta 2 microglobulin in the neonate. Acta Obstet Gynecol Scand 62 (1983) 311

Received August 24, 1989. Accepted October 16, 1989.

Dr. Vicente Barrio

Departamento de Nefrologia

Hospital "Reina Sofia"

Avda. Menéndez Pidal s/n

14004 Córdoba, Spain 